\title{
Changing Structure of Interest Rates
}

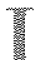

I $N$ RECENT MONTHS, fiscal and monetary actions have been very stimulative. Most recent data show few effects on spending and production, but expectations of expansion have risen. Reflecting these expectations, an unusually large volume of capital market issues has been marketed, and the yield curve on marketable securities has changed dramatically.
\end{abstract}

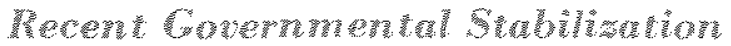 Achering}

Fiscal and monetary actions in recent months have been much more expansive than in late 1966 . These developments have probably contributed to bolstering current and future demands for goods and services.

The deficit in the Government's high-employment budget was at an $\$ 8$ billion annual rate in the first quarter of 1967 . This was a $\$ 1.1$ billion greater stimulus than during the first half of last year and $\$ 15$ billion larger than in the first half of 1965 . Increased Government spending for Vietnam was the key factor causing the change from late 1966 to early 1967 , but nondefense spending also rose. Budget stimulus continued during April and May.

Key monetary magnitudes have been expanding rapidly. Federal Reserve credit, adjusted for the effect of reserve requirement changes has increased at a 15 per cent annual rate since February and at a 16 per cent rate since November. ${ }^{1}$

Total reserves of member banks, adjusted for the effect of reserve requirement changes, have increased at an 8 per cent annual rate since February and at an 11 per cent rate since November. A chief source of reserves has been net Federal Reserve purchases of securities. In addition, reserve requirements on savings and certain other time deposits were lowered in March,

1 See this Bank's release "U.S. Financial Data"-Week ending May 31,1967 , freeing about $\$ 850$ million of reserves.

Some of the additional reserves have been needed to support a rapid increase in savings and other time deposits. Reserves available for private demand deposits have risen at an 8 per cent rate since February and at a 5 per cent rate since November. These reserves grew at an average rate of 2 per cent from 1960 to 1966. Changes in private demand deposits, the chief component of money, are closely related to this measure. Changes in total deposits and in bank credit (loans and investments) are more closely related to changes in total reserves.

Money supply, defined as demand deposits and currency in the hands of the public, has grown at an 8 per cent annual rate since February. The latest figures may be exaggerated by a shifting seasonal pattern, which limits the effectiveness of adjusting the data. Money has risen at a 5.4 per cent rate since last November. From 1960 to 1966 money rose at an average 3.2 per

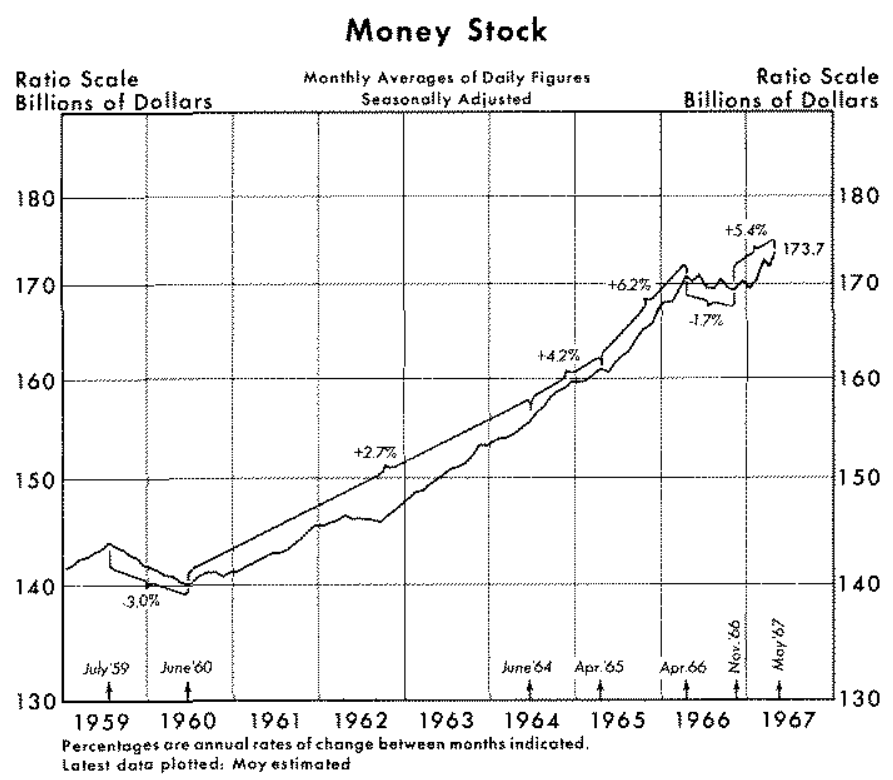


cent annual rate. The productive capacity of the economy is estimated to grow about 4 per cent a year.

The demand deposit component of money has risen at a 10 per cent rate since February and at a 5 per cent rate since November. Currency, the other component of the money stock, has risen at a more steady 6 per cent rate since November. From 1960 to 1966, demand deposits grew at a 2.8 per cent rate and currency at a 4.4 per cent rate.

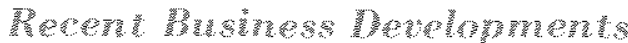

Spending and production have recently remained rather steady at a very high level. Through early May they had shown no clear response to the more expansionary fiscal and monetary actions, but such actions typically have their main impact on the economy after a few months lag. Total retail sales have changed little on balance since last summer. From 1960 to 1966 these sales trended upward at a 5.6 per cent annual rate.

Construction expenditures for the first quarter of 1967 were at a seasonally adjusted annual rate of $\$ 73$ billion, up from the fourth quarter of 1966 but 7 per cent below the first quarter last year. Industrial production declined at about a 5 per cent annual rate from the end of 1966 to April.

Unemployment has remained at 3.7 per cent of the labor force since last September, but demands for manpower have eased. Total employment has been about unchanged since December, after increasing 2.5 per cent last year. Payroll employment rose at a 2 per cent annual rate from December to April following a 5 per cent increase during 1966. By comparison, population of labor force age ( 18 to 64 ) has recently been rising at an estimated 1.6 per cent rate.

Price increases have continued to be more moderate in recent months than in early 1966. Consumer prices rose at a 1.4 per cent annual rate from last October to April, compared with a 4 per cent rate earlier in 1966. Industrial wholesale prices increased at a 1 per cent annual rate from last July to April, after rising at a 3 per cent rate in the first half of 1966. This index has been influenced by fluctuations of world-wide commodity prices. Quotations on farm products and on processed foods and feeds have declined since last fall to their late 1965 level.

Basic inflationary forces appear to have continued to prevail as final sales have increased at a rate of about 8 per cent a year since the fourth quarter, about twice the rate of increase of productive potential. The most general measure of price trends in the United States, as developed in the national income accounts, has been rising at a rate of about 3 per cent a year.

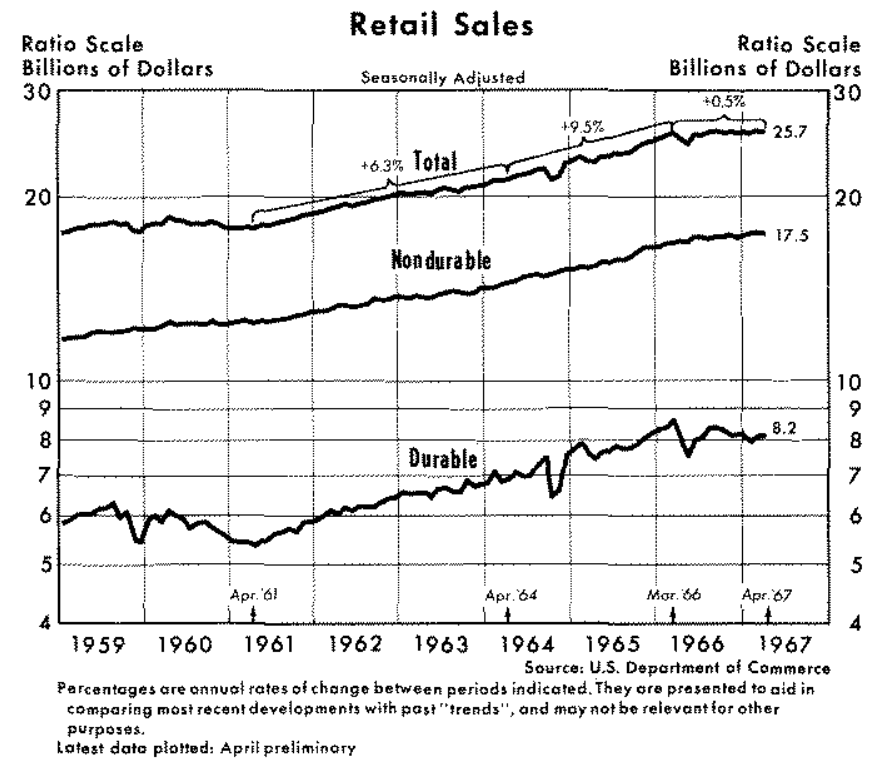

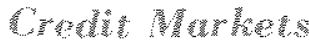

Demands for credit have been strong this year. The supply of new funds has also been great, reflecting both a large amount of saving and a marked monetary expansion. As a result, a substantial volume of funds has flowed through the money and capital markets. Estimates indicate that total borrowing amounted to a $\$ 70$ billion annual rate in the first quarter of 1967 , up $\$ 16$ billion from the previous quarter. Interest rates, the prices which equate the demands for and supplies of credit, have continued to decline in most short-term markets, but have risen on most long-term securities since the end of January.

Corporate demands for credit have been large. Estimated long-term corporate security offerings and placements were at a $\$ 22.5$ billion annual rate during the first four months of 1967, and the calendar of new offerings was heavy for May and June. By comparison, such offerings and placements were at a $\$ 19.6$ billion rate in the first four months last year and at an \$11.7 billion rate in the corresponding period of 1965. Business loans at commercial banks rose at a $\$ 9$ billion annual rate from December to April, or at a 12 per cent rate. According to reports from large banks, expansion slowed in May. The growth trend in business loans from 1956 to 1964 was 7 per cent per year; from 1964 to 1966 these loans jumped at a 17 per cent rate.

Municipal financing has also been large. From December to April estimated long-term security offerings and placements by state and local governments were at a $\$ 15$ billion annual rate. Rates for comparable periods of 1966 and 1965 were $\$ 12$ billion, and $\$ 10$ billion, respectively. 


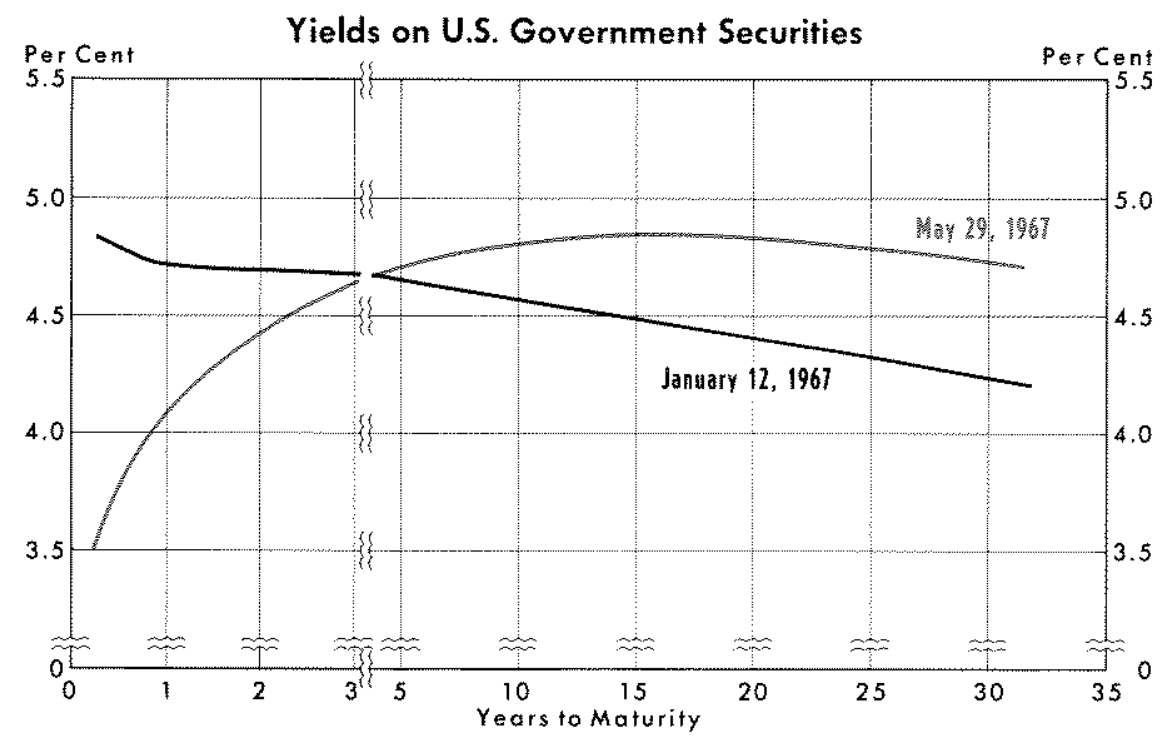

The recent developments are also consistent with another view of yield structures which holds that lenders and borrowers have a relatively high degree of mobility, at least at the margin, in selecting maturities. This view explains the various yield structures in terms of expectations of lenders and investors, particularly those engaged in arbitrage operations. ${ }^{3}$

The yield curve in mid-January was downward sloping; shortterm rates on Government securities were over half of one percentage point higher than the longest term rates. Such a relationship is consistent with market expectations of an approaching decline in

The Federal Government has also provided a strong upward influence on interest rates. The high-employment budget deficit was estimated at an $\$ 8$ billion annual rate in the first quarter of 1967 , and there are indications that the deficit is remaining near this level in the second quarter. By contrast, this budget showed a surplus at a $\$ 2$ billion rate in the first half of 1966 , at a $\$ 7$ billion rate in the first half of 1965 , and at a $\$ 12$ billion rate in the three years of 1961-1963.

\section{Structire of Interest Tates}

Interest rates have changed quite diversely since January. Long-term rates had declined late last year and early this year. In the past few months these rates have risen, reflecting current needs for new long-term funds and anticipations of higher rates to come. Shortterm rates, on the other hand, have continued to decline. Bank credit expansion-by the Federal Reserve System purchasing securities thereby enabling commercial bank lending and investing-has made more short-term funds available. In addition, some of the funds raised in the capital markets have been temporarily invested in short-term market instruments, tending to lower their yields.

The recent developments are consistent with the proposition that financial markets in the short run are largely segmented; that is that short-term rates are the result of demand and supply conditions in the short. term markets, while long-term rates reflect conditions in capital markets, and the various lenders and borrowers have a limited degree of flexibility in moving from one maturity sector to another. ${ }^{2}$

"See John Culbertson, "The Term Structure of Interest Rates," Quarterly Journal of Economics, November 1957, pp. 485-517. interest rates, possibly accompanying a slowdown in economic activity with lower demands for credit and expansionary monetary actions.

By late May, the slope of the yield curve had been reversed. Short-term interest rates on Government securities were $1^{1 / 4}$ percentage points lower than long-term rates. Investors and borrowers may be anticipating a general rise of interest rates. Rates generally tend to be pushed up by an acceleration of investment and expansion of economic activity and by large Government demands for credit. Borrowers who believe that yields will rise in the future are currently willing to pay more for long-term funds than for short-term funds. Lenders will accept lower rates on short loans than on long ones since they anticipate being able to relend the funds at higher rates in the near future.

Yield curves have taken various shapes in the past. ${ }^{4}$ For example, a year ago the curve had a marked hump in the intermediate-term range. Short-term yields were slightly above long-term rates but about one-half of a percentage point below the yield on 2-year issues. At that time, economic activity and demands for credit were rising rapidly, and market participants were expecting restrictive monetary actions in response to the excessive spending and inflationary pressures. Under these conditions lenders and borrowers might have

${ }^{3}$ David Meiselman, Tertn Structure of Interest Rates, (Englewood Cliffs: Prentice-Hall, 1962).

${ }^{4}$ See Sidney Homer, A History of Interest Rates, 1963 , pp. 380381 for a three-dimensional diagram presentation of successive yield curves on corporate securities beginning with the year 1900. An updating of these diagrams of changing yield curves to 1965 was presented in the book Term Structure of Interest Rates, Expectations, and Behavior Patterns by Burton Malkiel in 1966 on pp. $8-9$. 
expected short-term rates to rise further in the near future. At the same time, they might have believed that short-term rates over a somewhat longer period would most probably average below their current level. Such expectations are consistent with the humped yield curve.

The late spring of 1967 has been similar in some respects to 1963 . In both periods the economy had recently been on a plateau, but there were evidences of a strengthening in the demand for goods and services combined with optimistic outlooks. The shape of the yield curve in late May 1967 was nearly the same as in May 1963.

However, the current level of interest rates is one-half percentage point higher than four years ago.

The recent higher yields reflect several factors. The present demand for credit is stronger than it was in early 1963. The Federal Government is a much heavier net borrower. Private demands for funds may also be greater since the economy is operating closer to capac-

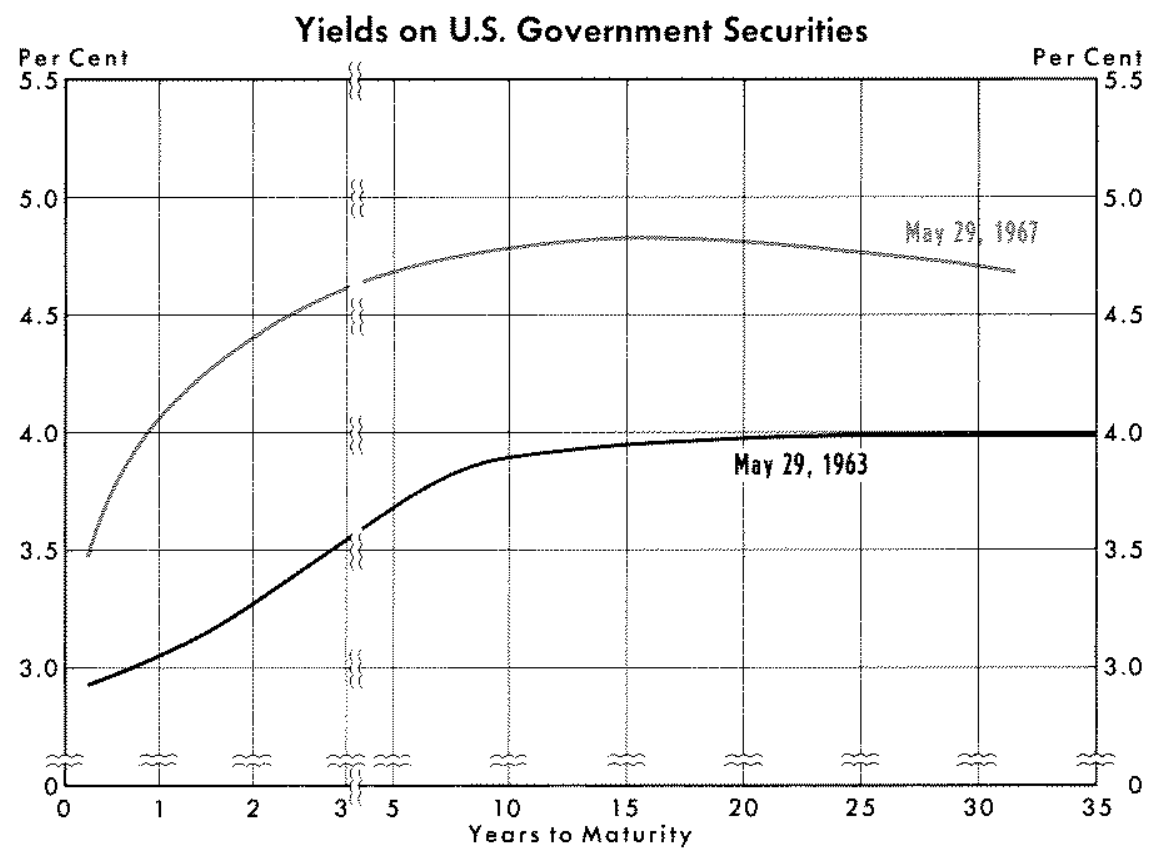

Yields on U.S. Government Securities

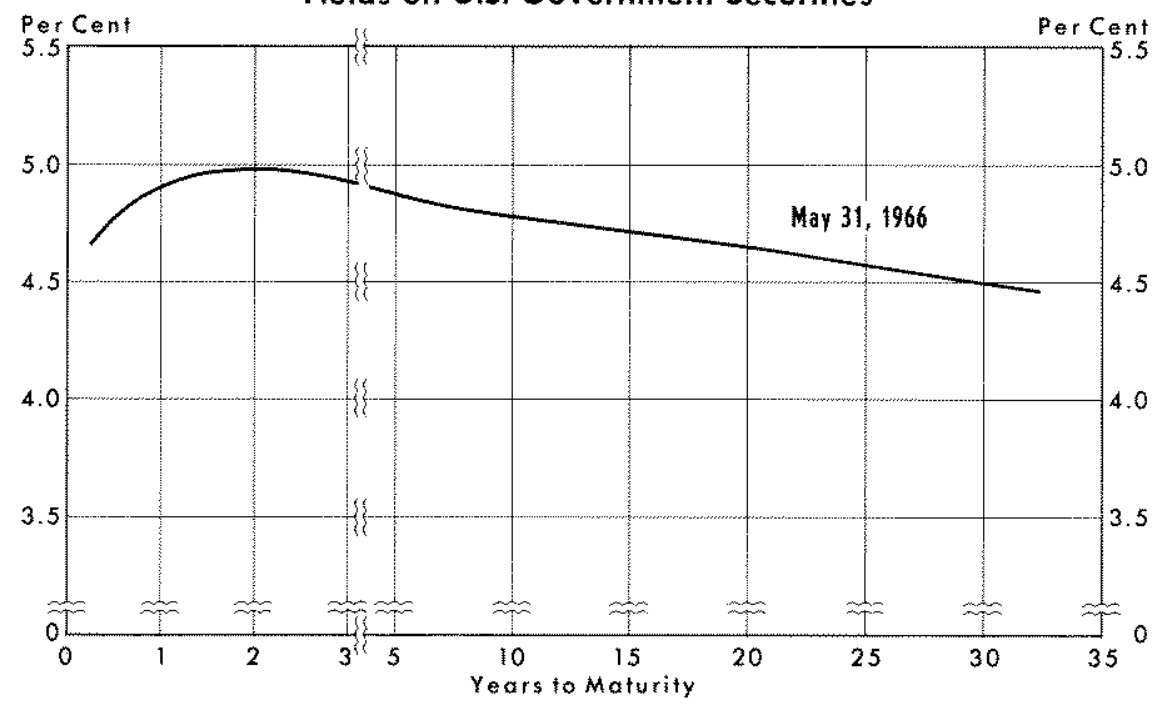

ity. Unemployment has amounted to 3.7 per cent of the labor force in recent months compared with 5.7 per cent in the spring of 1963.

Borrowers and lenders probably have greater expectations of price increases now than they did in early 1963. From late 1965 to early 1967 over-all prices rose at a 3.4 per cent annual rate compared with a 1.3 per cent rate from late 1961 to early 1963. Inflation makes the quoted market rate higher than the real rate of interest. Borrowers repay in cheaper dollars, and lenders lose purchasing power.

If it is true, as some recent studies indicate, that expectations largely determine yield structures, ${ }^{\text {; }}$ official actions designed to change an existing structure, referred to as "operation twist," may accomplish little. Other suppliers of funds would tend to lend for shorter periods, and borrowers would tend to lengthen their debt maturities.

\footnotetext{
"Franco Modigliani and Richard Sutch, "Innovations in Interest Rate Policy," American Economic Review, May 1966, pp. 178-197,
} 